\title{
A novel bioactive peptide from yoghurts modulates expression of the gel-forming MUC2 mucin as well as population of goblet cells and Paneth cells along the

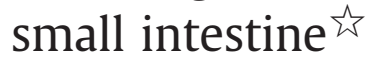

\author{
${\text { Pascale Plaisanciéa,b,* }{ }^{\mathrm{a}} \text { Jean Claustre }}^{\mathrm{c}}$, Monique Estienne ${ }^{\mathrm{a}, \mathrm{b}}$, Gwénaële Henry ${ }^{\mathrm{d}, \mathrm{e}}$, Rachel Boutrou ${ }^{\mathrm{d}, \mathrm{e}}$, \\ Armelle Paquet $^{\mathrm{a}}$, Joëlle Léonil ${ }^{\mathrm{d}, \mathrm{e}}$ \\ a INRA USC1235, INSERM U1060, CarMeN laboratory, F-69621 Villeurbanne, France \\ ${ }^{\mathrm{b}}$ INSA-Lyon, IMBL, F-69621 Villeurbanne, France \\ 'INSERM UMR1052/CNRS UMR5286, Cancer Research Center of Lyon, Team 4, Faculty Laennec, Lyon, and University Lyon 1, F-69000 Lyon, France \\ dINRA, UMR1253, F-35042 Rennes, France \\ e AGROCAMPUS OUEST, UMR1253, F-35042 Rennes, France
}

Received 10 November 2011; received in revised form 1 May 2012; accepted 2 May 2012

\begin{abstract}
Several studies demonstrated that fermented milks may provide a large number of bioactive peptides into the gastrointestinal tract. We previously showed that beta-casomorphin-7, an opioid-like peptide produced from bovine $\beta$-casein, strongly stimulates intestinal mucin production in ex vivo and in vitro models suggesting the potential benefit of milk bioactive peptides on intestinal protection. In the present study, we tested the hypothesis that the total peptide pool (TPP) from a fermented milk (yoghurt) may act on human intestinal mucus-producing cells (HT29-MTX) to induce mucin expression. Our aim was then to identify the peptide(s) carrying the biological activity and to study its impact in vivo on factors involved in gut protection after oral administration to rat pups (once a day, 9 consecutive days). TPP stimulated MUC2 and MUC4 gene expression as well as mucin secretion in HT29-MTX cells. Among the four peptide fractions that were separated by preparative reversed-phase high-performance liquid chromatography, only the C2 fraction was able to mimic the in vitro effect of TPP. Interestingly, the sequence [94-123] of $\beta$-casein, present only in C2 fraction, also regulated mucin production in HT29-MTX cells. Oral administration of this peptide to rat pups enhanced the number of goblet cells and Paneth cells along the small intestine. These effects were associated with a higher expression of intestinal mucins (Muc2 and Muc4) and of antibacterial factors (lysozyme, rdefa5). We conclude that the peptide $\beta-\mathrm{CN}(94-123)$ present in yoghurts may maintain or restore intestinal homeostasis and could play an important role in protection against damaging agents of the intestinal lumen.
\end{abstract}

(c) 2013 Elsevier Inc. All rights reserved.

Keywords: Milk bioactive peptides; $\beta$-Casein; Intestinal barrier; Intestinal protection; MUC2; Mucus; $\alpha$-Defensin

\section{Introduction}

Milk proteins are considered as the most important sources of bioactive peptides. These remain inactive within the sequence of the parent protein until they are released by either gastrointestinal digestion or food processing. Their beneficial health effects are

Abbreviations: CT, controls; ELLA, enzyme-linked lectin assay; PC, Paneth cell; rdefa5, rat defensin 5; TCA, trichloroacetic acid; TFA, trifluoroacetic acid; $\mathrm{TP}$, treated with peptide; TPP, total peptide pool; $\beta$-CN, $\beta$-casein; $\beta$-CMs, $\beta$ casomorphins; $\beta$-CM-7, $\beta$-casomorphin-7.

This project has been funded in part by Arilait Recherches (Paris, France) and by grants from INRA Prevalorisation project "Pept94-MUC."

* Corresponding author. INRA USC1235, INSERM U1060, Cardiovascular Metabolism diabetes and Nutrition Laboratory, CarMeN, Bâtiment IMBL, INSA-Lyon, 11 avenue Jean Capelle, 69621 VILLEURBANNE Cedex, France. Tel.: + 334724381 13; fax: + 33472438524 .

E-mail address: pascale.plaisancie@inserm.fr (P. Plaisancié). classified as antimicrobial, immunomodulatory, blood-pressurelowering (ACE inhibitory), antithrombotic, antioxidant and opioidlike, in addition to cholesterol-lowering and enhancers of mineral absorption/bioavailability [1,2]. $\beta$-Casomorphins $(\beta-C M s)$ are such a family of opioid peptides derived from bovine $\beta$-casein. They possess $\mu$-preferential-receptor agonist activity and consist of $\beta-\mathrm{CM}$ $7,-6,-5$ and -4 which are obtained by successive C-terminal cleavage of the [60-66] (Tyr-Pro-Phe-Pro-Gly-Pro-Ile) sequence in bovine $\beta$-casein [3]. Jinsmaa and Yoshikawa have also isolated another opioid peptide (Tyr-Pro-Val-Glu-Pro-Phe) after digestion of bovine $\beta$-casein by proteases [4]. It corresponds to residues [114$119]$ of $\beta$-casein and was named neocasomorphin-6. Interestingly, $\beta$-CMs and neocasomorphin-6 are resistant to the actions of gastrointestinal enzymes due to the presence of proline residues. They could thus reach the intestine and represent agonists for opioid receptors localized in the gut myenteric and submucosal plexus but also on epithelial cells of the human, rat, pig and guinea pig [5-7]. 
Intestinal goblet cells are highly polarized secretory cells that reside throughout the length of the small and large intestine. They are responsible for production of the protective mucus coat by releasing the secreted mucin MUC2 (in rodent, Muc2), a high-molecularweight glycoprotein that is stored within granules in their apical compartment. Mucus lubricates the intestinal surface, limits passage of luminal molecules into the mucosa, functions as a dynamic defensive barrier against enteric pathogens and acts as a substrate and a niche which the commensal flora can colonize $[8,9]$. The physiological relevance of MUC2 is definitively proven by the development of spontaneous colitis and intestinal tumors in Muc2 knockout mice $[10,11]$. In man, many studies also support the hypothesis that alterations in mucin synthesis, secretion and/or degradation are involved in the initiation or maintenance of a lot of intestinal disorders. For example, Pugh et al. demonstrated that active duodenal ulcerations were associated with a decreased number of goblet cells [12]. In ulcerative colitis, mucus layer and goblet cell density are also significantly reduced $[13,14]$. Based on these observations, the strengthening of mucus gel, in particular by nutrients, could be extremely beneficial [15]. In order to achieve this aim, we previously showed that luminal administration of $\beta-C M-$ 7 induced a strong and fast (in the first 30 min of stimulation) release of mucin in rat jejunum through the activation of the enteric nervous system and opioid receptors $[16,17]$. Additionally, we demonstrated that $\beta-C M-7(100 \mu \mathrm{mol} / \mathrm{L})$ can also directly act on mucus-secreting cells to induce the expression of Muc2 and Muc3 in intestinal rat cells (DHE) or the expression of MUC5AC in intestinal human cells (HT29MTX) [7]. $\beta-C M s$ could thus regulate intestinal goblet cells via two distinct but complementary modes of action: by a direct pathway to increase the expression of intestinal mucin genes and by an indirect nervous pathway to rapidly enhance the secretory activity of intestinal goblet cells. These findings were very exciting and suggested that the presence of $\beta$-CMs in the intestinal lumen could improve gut health. It is necessary however to bring sufficient quantities of bioactive peptide in contact with intestinal target cells. $\beta$-CMs may be generated from native bovine milk $\beta$-casein as a result of enzymatic hydrolysis occurring in the digestive tract [18] or during technological processing of food [19]. Indeed, several studies indicated that proteolytic systems involved in fermented milks or cheese manufacture can hydrolyze $\beta$-casein to $\beta-\mathrm{CM}-7$ or $\beta$ casomorphin precursors, as well as to numerous other bioactive peptides $[1,20,21]$. In this context, the main objective of our project was to determine if opioid peptides (or the precursors thereof, or possibly other peptides) present in yoghurts are able to stimulate the production of intestinal mucins, which would then make these dairy products a valuable way for increasing the intestinal protection. For this purpose, the total peptide pool (TPP) from a marketed yoghurt and four fractions obtained by preparative reversed-phase highperformance liquid chromatography (RP-HPLC) from this pool were tested in vitro in a human mucus-secreting cell line (HT29-MTX). $\beta$ casein f94-123 [ $\beta-\mathrm{CN}(94-123)]$, a precursor of the sequence of neocasomorphin-6, was detected only in the active fraction and was assumed to be the active peptide. Accordingly, it was tested in the same cell line but also in rat pups to determine its in vivo effects and to study its impact on several actors of intestinal protection.

\section{Materials and methods}

\subsection{Peptide fraction collection from yoghurt}

\subsubsection{Preparation of the TPP from marketed yoghurt}

Commercial yoghurt was manually mixed and centrifuged at $5000 \mathrm{~g}$ for $30 \mathrm{~min}$ at room temperature. The pellet was discarded, and the peptide fraction was isolated from the supernatant by addition of $2 \%$ trichloroacetic acid (TCA) ( $w / v$, final concentration). After 30-min equilibration, the sample was centrifuged at $5000 \mathrm{~g}$ for $10 \mathrm{~min}$. The supernatant containing TPP was filtered through Whatman no. 41 filter paper to remove floating particles. Part of this solution was directly frozen and used for fractionation. The other part was dialyzed against osmosed water and lyophilized.

\subsubsection{Fractionation of the TPP by chromatography}

One hundred twenty milliliters of TPP was filtered through $1.2-\mu \mathrm{m}$ pore filters and then separated on a preparative C18 column (LiChrospher RP18, $12 \mu \mathrm{m}$, Merck, $250 \times 50 \mathrm{~mm}$ ) equilibrated in $1.06 \%$ o trifluoroacetic acid (TFA; Sigma-Aldrich, St.Quentin Fallavier, France). Elution was achieved at $45 \mathrm{ml} / \mathrm{min}$ with a multistep gradient of acetonitrile in 1\% TFA. The absorbance was monitored at $214 \mathrm{~nm}$. Five fractions, named $\mathrm{C} 1$ to $\mathrm{C} 5$, eluted at $12 \%, 24 \%, 36 \%, 48 \%$ and $80 \%$ of acetonitrile, respectively, were collected and lyophilized at neutral $\mathrm{pH}$. $\mathrm{C} 1$ fraction was found in too low quantity to be analyzed.

\subsubsection{Analysis of peptides by RP-HPLC}

TPP and fractions were analyzed by RP-HPLC on a Waters HPLC system (Waters 2695 Separators Module, Alliance, Waters, Milford, MA, USA) with a narrow-bore symmetry C18 column ( 5 - $\mu$ m particle size, $2.1 \times 150 \mathrm{~mm}$, Waters) equipped with a C18 cartridge guard. Solvent A contained $1.06 \%$ (v/v) TFA in Milli Q water, and solvent B contained $1 \%$ 。 (v/v) TFA in acetonitrile-Milli Q water (80:20).

Separation of peptides was obtained using a linear gradient from $0 \%$ to $60 \%$ of solvent B for $60 \mathrm{~min}$. The column was maintained at $40^{\circ} \mathrm{C}$, the flow rate was $0.25 \mathrm{ml} /$ min, and eluted peaks were detected by UV absorbance at 214 and $280 \mathrm{~nm}$ (Waters 2487 Dual $\lambda$ Absorbance Detector). Before analysis, samples were first diluted in solvent $A$ and then filtered through $0.45-\mu \mathrm{m}$ pore filters. For quantification of $\beta-\mathrm{CN}(94-$ $123)$, the mass spectrometer was used as a detector. The surface of specific ions resulting from the ionization of different concentrations of the chemically synthesized peptide (GENOSPHERE Biotechnologies, Paris, France) was determined and used as a calibration curve.

2.1.4. Identification of peptides by liquid chromatography-tandem mass spectrometry (LC-MS-MS)

Peptides were identified using nano-LC-MS-MS as described by Boutrou et al. [22], with some modifications. Samples were diluted in $1 \%$ TFA, and $5 \mu \mathrm{l}$ was injected into a capillary column. The separation was achieved with a linear gradient from $5 \%$ to $50 \%$ solvent B for $45 \mathrm{~min}$. Solvent A contained 2\% acetonitrile, $0.8 \%$ 。 formic acid and $0.1 \%$ TFA in LC-grade water, and solvent B contained 95\% acetonitrile, $0.8 \%$ formic acid and $0.1 \%$ TFA in LC-grade water. Peptides were then identified using the Mascot MS/MS ion search V.2.2. from Matrix Science (Boston, MA, USA) against a homemade database dealing with major milk proteins.

\subsection{In vitro studies}

HT29-MTX, a human colon carcinoma-derived mucin-secreting goblet cell line, was grown in 25-cm plastic culture flasks in Dulbecco's modified Eagle's medium supplemented with $10 \%$ fetal bovine serum and $100 \mathrm{mg} / \mathrm{ml}$ penicillin-streptomycin at $37^{\circ} \mathrm{C}$ in a $5 \% \mathrm{CO}_{2}$ atmosphere in a humidified incubator as previously described [7]. To study the effect of peptide pool and fractions, cells were seeded in 12-well culture plates. Experiments were performed 21 days after cells reached confluency (see Supplemental data). All experiments were performed at least three times in triplicate.

\subsection{In vivo studies}

\subsubsection{Animals}

Primiparous timed-pregnant Wistar female rats were purchased (Janvier ; route des chênes secs, 53940 Le Genest Saint Isle, France) on gestational day 14. Dams were individually housed on a 12:12-h light-dark cycle with free access to food and water. The day of birth was considered to be postnatal day 1 . Litters were culled to nine pups. All procedures were approved by the regional ethics committee for animal experiment (Rhone Alpes, approval no. 0195).

\subsubsection{Experimental protocol}

Peptide $\beta-C N(94-123)$ was synthesized from GENOSPHERE Biotechnologies. The daily required amount of the drug was freshly dissolved in sterile water for the gavage procedure or in culture medium for in vitro studies.

Rat pups ( $n=9$ per group) were randomly assigned to receive treatment by gastric gavage ( $10 \mu \mathrm{l} / \mathrm{g}$ body weight) with either water (control group, $\mathrm{CT}$ ) or $\beta-\mathrm{CN}(94-123)$ at $0.01,0.1$ and $100 \mu \mathrm{mol} / \mathrm{L}$ every day from postnatal day 10 to postnatal day 18 . Treatment was delivered at the same time every day to minimize the effects of circadian rhythm. Body weight was recorded daily. Two hundred forty minutes after the last administration, rats were deeply anesthetized with pentobarbital sodium. Intestinal samples were taken for immunohistological and biochemical studies. RNA and protein were obtained from the same sample by using Nucleospin RNA/Protein kit (Macherey-Nagel GmbH \& Co KG, Germany) according to the manufacturer's protocol.

\subsection{Enzyme-linked lectin assay (ELLA) for mucins from cell culture media}

An ELLA was used to measure mucin-like glycoprotein secretion as described in the Supplemental data. The amount of glycoprotein secreted in the incubation medium 
Table 1

Antibodies used for Western blot analysis

\begin{tabular}{llll}
\hline Antigen & Species & Source & Dilution \\
\hline MUC4 & Mouse & Abcam (ab60720) & $1: 1000$ \\
Lysozyme & Rabbit & Interchim (GTX72913) & $1: 250$ \\
Cyclophilin A & Rabbit & Cell signaling Technology (2175) & $1: 1000$ \\
\hline
\end{tabular}

was expressed as nanograms of mucin-like glycoprotein per $10^{6}$ cells, and results are given as percent of controls.

\subsection{Quantitative real-time polymerase chain reaction (PCR) analysis}

Measures were performed with the real-time fluorescence detection method using the ep realplex Mastercycler (Eppendorf) with Maxima SYBR Green qPCR Master Mix (Fermentas) in PCR plates (see Supplemental data). Calculations were performed according to the $2^{-\Delta \Delta \mathrm{Ct}}$ method with correction for efficiency, and the final value was adjusted so that controls had a mean relative mRNA level of $1[23,24]$.

\subsection{Western blot analysis}

Proteins $(30 \mu \mathrm{g})$ were separated using Nupage gel bis-Tris $10 \%$ (lysozyme, cyclophilin) or Tris acetate 3\%-8\% (Muc4) and then transferred onto polyvinylidene difluoride (PVDF) membrane using an XCELL II Blot Module (Invitrogen Life Technologies SAS, Villebon sur Yvette, France). The membrane was incubated with antibodies directed against a mouse monoclonal anti-MUC4 antibody, a rabbit polyclonal anti-lysozyme antibody or a rabbit polyclonal anti-cyclophilin A antibody. Primary antibodies are listed in Table 1. Bound antibodies on the PVDF membrane were detected using WesternBreeze Immunodetecting Chemiluminescent System (Invitrogen). The optical density of protein bands was visualized and pixelized with the "Image System" (ImageMAster VDS-CL, Amersham Bio-sciences) and densitometrically analyzed with Quantity one image analysis software (Biorad Laboratory, Hercules, CA, USA).

\subsection{Histological examination of intestine for goblet and Paneth cells (PCs) determination}

Intestinal tissues were removed, fixed in $90 \%$ ethanol for $24 \mathrm{~h}$ at $-20^{\circ} \mathrm{C}$ and processed into paraffin. Serial paraffin sections $(4 \mu \mathrm{m})$ were rehydrated and treated as described in the Supplemental data. All slides were analyzed by a single investigator who was blinded to the treatment groups. The histological features shown are representative of all tissue samples studied.

\subsection{Statistical analysis}

In vitro data were compared using repeated-measures analysis of variance (ANOVA) followed by the Mann-Whitney $U$ test when appropriate or Mann-Whitney test alone for single comparisons. In dose-effect studies performed in vivo, data were analyzed by one-way ANOVA followed by Bonferroni test when appropriate. Western blot data obtained after gavage treatment were compared by Mann-Whitney test. All the data are expressed as mean \pm S.E.M. Differences with $P<.05$ were considered significant. Statistical analyses were performed with XLSTAT, Version 2009.4.06 (Addinsoft, Paris, France).

\section{Results}

\subsection{The peptide pool from a marketed yoghurt stimulated mucin} secretion and expression in the human mucin-secreting cell line HT29-MTX

The peptidic fraction of marketed yoghurt was recovered in the supernatant after centrifugation. The TPP corresponded to the $2 \%$ TCA-soluble fraction. On the basis of their total nitrogen content as determined by a micro-Kjeldahl analysis [25], TPP represented about $10 \%-13 \%$ of the total protein nitrogen of yoghurt. As shown by analytical RP-HPLC analysis (Fig. 1A), the elution pattern of the TPP was very complex, with numerous peaks arising from the protease and peptidase action during milk fermentation. To assess the effect of TPP on goblet cells and mucin production, we used the human intestinal HT29-MTX cell line which secretes mucin in response to various stimulants [7]. These cells also exhibited immunopositivity for $\mu$-opioid receptors on their cell membranes [7]. The major mucin produced by HT29-MTX cells is the secreted mucin MUC5AC. We also studied MUC2 and MUC4 which represent, respectively, the major intestinal secreted mucin and one of the transmembrane-associated mucins. Cell cultures were exposed to different concentrations of TPP $(\mathrm{Y} / 5, \mathrm{Y} / 2$ and $\mathrm{Y})$ for $4 \mathrm{~h}$. The $\mathrm{Y}$ concentration corresponds to the concentration of these peptides in the initial yoghurt. As shown in Fig. 1B, TPP induced the secretion of mucin-like glycoprotein (maximal response: $192 \% \pm 3 \%$ of controls, $P<.05$ ). The effect of TPP on the expression of MUC2, MUC5AC and MUC4 was then evaluated. Quantitative reverse transcriptase (RT)-PCR showed that TPP induced a dose-dependent increase in MUC2 and MUC4 mRNA levels compared with controls (Supplemental Fig. 1). The maximal response was obtained with Y concentration $(220 \% \pm 24 \%$ and $177 \% \pm 12 \%$ of controls for MUC2 and MUC4, respectively; $P<.05$ ). In contrast, TPP did not modify the expression of MUC5AC. These results suggest that, tested at a level consistent with that found in yoghurt, the TPP is able to modulate mucin production.

\subsection{Selective effect of a peptide fraction obtained from the peptide pool} on mucin secretion and expression in HT29-MTX cells

TPP was then separated by preparative RP-HPLC. The profiles of fractions are presented in Fig. 2A. The fraction $\mathrm{C} 1$ corresponded to the
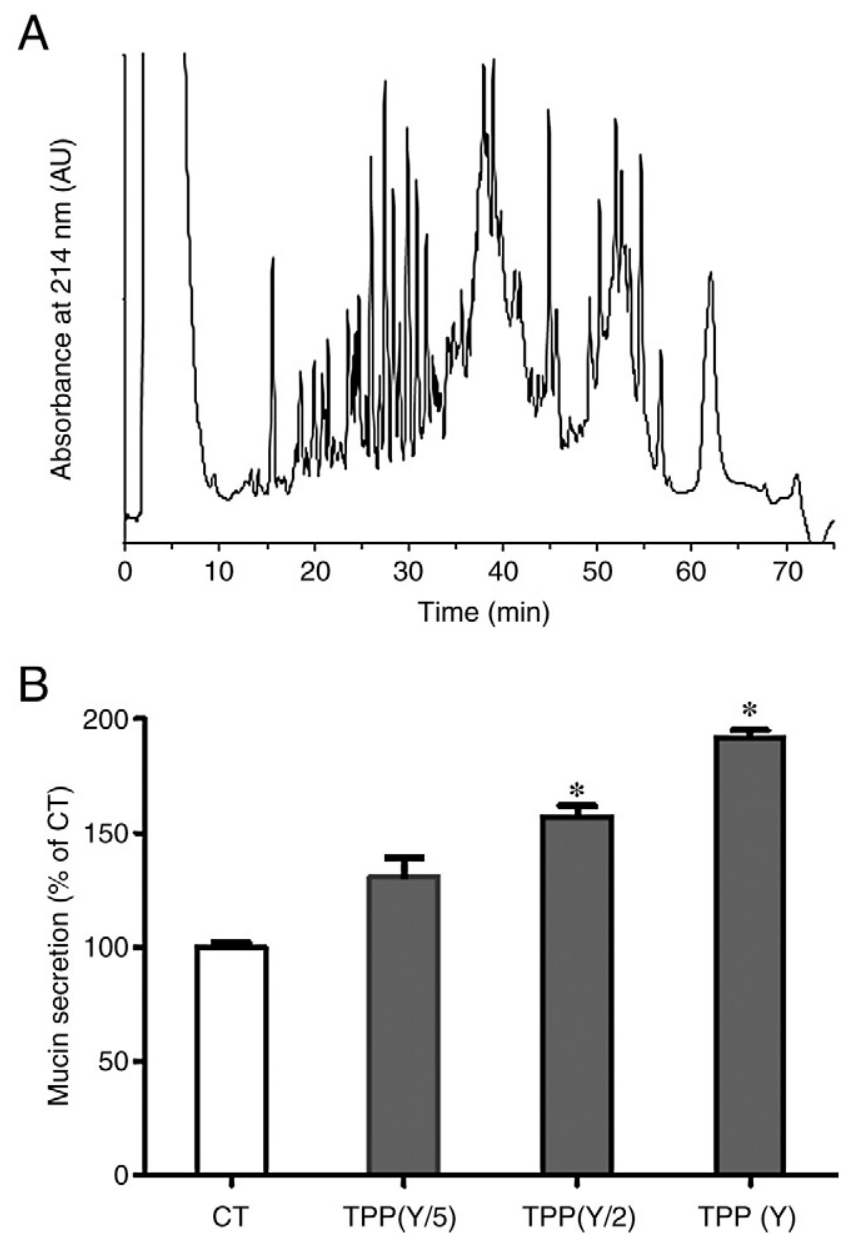

Fig. 1. TPP from yoghurt (see Methods) stimulates mucin glycoprotein secretion in HT29-MTX cells. (A) RP-HPLC elution profile of the TPP of a marketed yoghurt. Samples were analyzed by RP-HPLC on a Symmetry column $(150 \times 2.1 \mathrm{~mm}$ i.d.), and elution was performed at a flow rate of $0.25 \mathrm{ml} / \mathrm{min}$ at $40^{\circ} \mathrm{C}$, with a linear gradient from $0 \%$ to $60 \%$ of solvent B for $60 \mathrm{~min}$. Solvent A contained 0.106\% TFA (v:v) in Milli-Q water, and solvent B contained $0.1 \%$ TFA (v:v) and $80 \%$ acetonitrile (v:v) in Milli-Q water. (B) Dose response for TPP stimulation ( $4 \mathrm{~h}$ ) of mucin glycoprotein release in HT29-MTX cells. The Y concentration corresponds to the content of TPP in the initial yoghurt. The amount of mucin glycoproteins in culture media was measured by ELLA. The data are expressed as mucin glycoproteins secretion in percent of control. Each point represents mean \pm S.E.M. of three to four experiments performed in triplicate. ${ }^{*} P<.05$ vs. controls. 
A

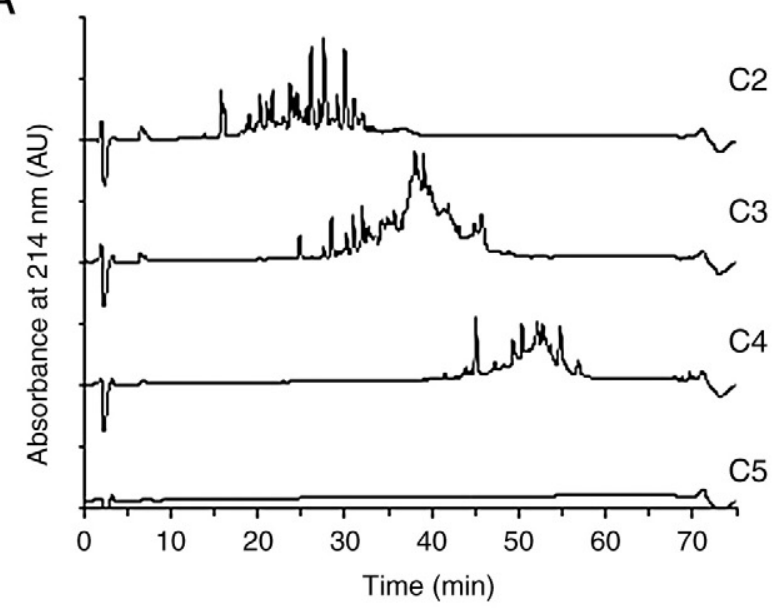

B

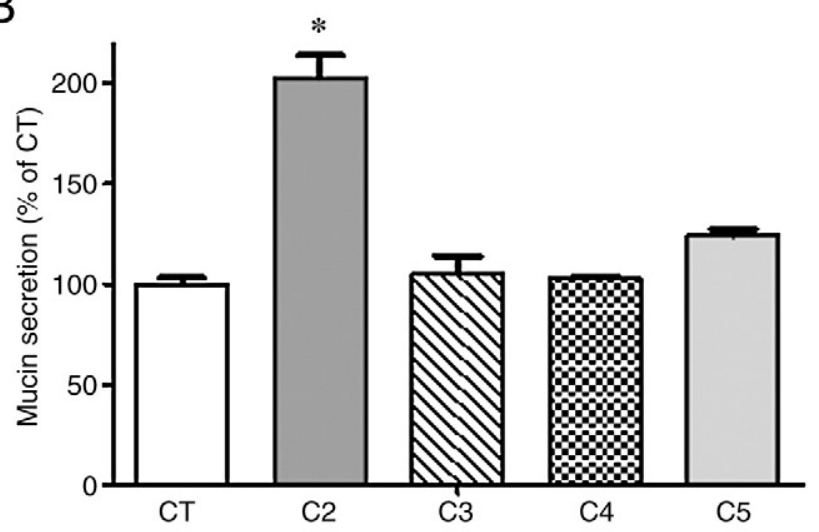

C

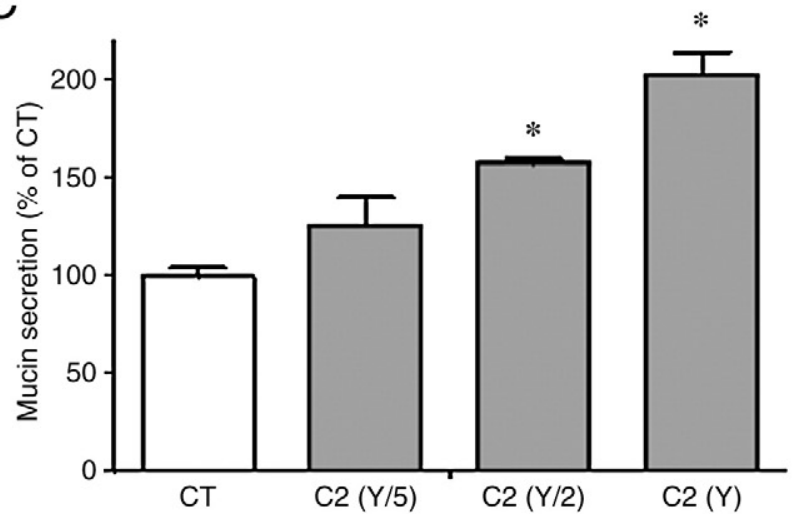

Fig. 2. C2 fraction stimulates mucin glycoprotein secretion in HT29-MTX cells. (A) RPHPLC elution profile of peptide fractions (C2 to C5). See Fig. 1 for details. (B) Effect of different fractions ( $\mathrm{C} 2$ to $\mathrm{C} 5$ ) of the peptide pool on mucin glycoprotein secretion ( $\mathrm{Y}$ concentration, $4 \mathrm{~h}$ ). The Y concentration corresponds, for each fraction, to the content of peptides in the initial yoghurt. The amount of mucin glycoproteins in culture media was measured by ELLA. The data are expressed as mucin glycoproteins secretion in percent of control. Each point represents mean \pm S.E.M. of three to four experiments performed in triplicate. ${ }^{*} \mathrm{P}<.05$ vs. controls. (C) Dose response for $\mathrm{C} 2$ fraction stimulation on mucin glycoprotein secretion. Each point represents mean \pm S.E.M. of three to four experiments performed in triplicate. ${ }^{*} P<.05$ vs. controls.

elution of TCA. The whole peptide profile was recovered in four fractions (C2, C3, C4 and C5). The identification of peptides, by using LC-MS-MS, showed that C2, C3 and C4 contained a mixture of about 60 identified peptides, of which more than half (50\%-80\%) were derived from $\beta$-casein. In the $\mathrm{C} 5$ fraction, only six peptides were identified, of which five were from $\beta$-casein. Table 2 is a selection of identified peptides, focused on precursors of $\beta-\mathrm{CM}-7$ and neocasomorphin-6, i.e., containing the [60-66] and [114-119] region of $\beta$ casein, respectively. In $C 2$ fraction, we identified three peptides ( $\beta$ casein f94-123, f102-123 and f106-123) which may be precursors of the agonist opioid neocasomorphin-6 (sequence [114-119] of $\beta$ casein) [4]. The C3 fraction contained five potential precursors of neocasomorphin-6 ( $\beta$-casein f100-123, f102-123, f106-119, f106-123 and f108-123) and three peptides ( $\beta$-casein f57-68, f57-72 and f5972 ) which are precursors of $\beta-C M-7$ ( $\beta$-casein $f 60-66$ ). Three peptides containing the sequence [60-66] of $\beta$-casein were identified in fraction C4 ( $\beta$-casein f57-77, f57-91 and f57-93). The $C 5$ fraction contained none in the zones of interest.

The C2-C5 fractions collected were tested for their mucin production activity in HT29-MTX cells. As shown in Fig. 2B, the overall release of mucin-like glycoprotein was raised after $4 \mathrm{~h}$ of exposure to C2 fraction only. This effect of C2 was dose dependent (Fig. 2C). Quantitative RT-PCR analysis also revealed that C2 fraction significantly increased MUC2 and MUC4 mRNA levels as compared with controls (Supplemental Fig. 2). As observed in Table 2, the peptide sequence [94-123] of $\beta$-casein is the only peptide present only in the active fraction $\mathrm{C} 2$. It may therefore be responsible for the observed biological effect. It was named peptide $\beta-\mathrm{CN}(94-123)$.

3.3. Peptide $\beta-C N(94-123)$, a peptide we detected in yoghurts, regulated the secretion and the expression of mucins in HT29-MTX cells

The presence of $\beta-\mathrm{CN}(94-123)$ was investigated in different marketed regular yoghurts, i.e., fermented with only Lactobacillus delbrueckii ssp. bulgaricus and Streptococcus salivarius ssp. thermophilus. $\beta-\mathrm{CN}(94-123)$ was detected in $80 \%$ of tested yoghurts at concentrations ranging between 0.3 and $1.7 \mu \mathrm{mol} / \mathrm{L}$. The identification failed on some yoghurts, probably because the concentration of peptide was below the detection threshold. Hence, this peptide seems to be released by the bacteria used in the manufacture of yoghurts. Accordingly, the peptide corresponding to the sequence of $\beta$-Casein f94-123 (GVSKVKEAMAPKHKEMPFPKYPVEPFTESQ) was chemically synthesized and tested on HT29-MTX cells.

As shown in Fig. 3A, $\beta-\mathrm{CN}(94-123)(0.01-1 \mu \mathrm{mol} / \mathrm{L})$ dosedependently induced mucin-like glycoprotein secretion. Peptide $\beta$ $\mathrm{CN}(94-123)$ also increased the expression of MUC2 and MUC4 after $4 \mathrm{~h}$ of stimulation (Fig. 3B and 3C) but not that of MUC5AC (data not shown). The first significant increase in transcripts was observed with a concentration of $0.01 \mu \mathrm{mol} / \mathrm{L}$ for MUC2 and MUC4. These data indicate that $\beta-\mathrm{CN}(94-123)$, tested at concentrations close to those detected in yoghurts, was able to reproduce the effect of the TPP and of the relevant $\mathrm{C} 2$ fraction. In contrast, $\beta-\mathrm{CN}(94-123)$, tested at a concentration of $100 \mu \mathrm{mol} / \mathrm{L}$, inhibited the expression of MUC4.

In an attempt to determine the mechanisms involved in the effect of $\beta-\mathrm{CN}(94-123)$, HT29-MTX cells were pretreated for $30 \mathrm{~min}$ at $37^{\circ} \mathrm{C}$ with the mu-opioid antagonist cyprodime $\left(10^{-5} \mathrm{~mol} / \mathrm{L}\right)$ before addition of $0.1 \mu \mathrm{mol} / \mathrm{L} \beta-\mathrm{CN}(94-123)$ for $4 \mathrm{~h}$. Interestingly, the effects of $\beta-\mathrm{CN}(94-123)$ on HT29-MTX cells were not prevented by pretreatment with the mu-opioid antagonist (data not shown).

\subsection{In vivo effects of peptide $\beta-C N(94-123)$}

To determine the physiological relevance of the findings obtained from cultured goblet-like cells, pups received synthetic peptide $\beta$ $\mathrm{CN}(94-123)(0.01,0.1$ and $100 \mu \mathrm{mol} / \mathrm{L})$ or vehicle alone (CT rats) by oral gavage once daily for 9 consecutive days. No significant difference in body weight was observed between rats treated with the peptide (TP rats) and CT rats. The morphology of the intestine of rats subjected to $\beta-\mathrm{CN}(94-123)$ treatment was also normal. We assessed mucosal proliferation by determining proliferating cell nuclear 
Table 2

Identification by nano-LC-MS-MS of peptides present in fractions obtained from a marketed fermented milk

\begin{tabular}{|c|c|c|c|c|}
\hline Fraction & Region & $\beta$-casein sequence & Peptide sequence & Molecular weight \\
\hline \multirow[t]{3}{*}{$\mathrm{C} 2$} & Opioid region & f94-123 & GVSKVKEAMAPKHKEMPFPKYPVEPFTESQ & 3417.9 \\
\hline & & f102-123 & MAPKHKEMPFPKYPVEPFTESQ & 2619.0 \\
\hline & & f106-123 & HKEMPFPKYPVEPFTESQ & 2191.4 \\
\hline \multirow[t]{8}{*}{$\mathrm{C} 3$} & Pro- $\beta-C M s$ & f57-68 & SLVYPFPGPIPN & 1300.5 \\
\hline & & f57-72 & SLVYPFPGPIPNSLPQ & 1726.0 \\
\hline & & f59-72 & VYPFPGPIPNSLPQ & 1525.7 \\
\hline & Opioid region & f100-123 & EAMAPKHKEMPFPKYPVEPFTESQ & 2819.2 \\
\hline & & f102-123 & MAPKHKEMPFPKYPVEPFTESQ & 2619.0 \\
\hline & & f106-119 & HKEMPFPКYPVEPF & 1746.0 \\
\hline & & f106-123 & HKEMPFPKYPVEPFTESQ & 2191.4 \\
\hline & & f108-123 & EMPFPKYPVEPFTESQ & 1926.1 \\
\hline \multirow[t]{3}{*}{$\mathrm{C} 4$} & Pro- $\beta-C M s$ & f57-77 & SLVYPFPGPIPNSLPQNIPPL & 2260.6 \\
\hline & & f57-91 & SLVYPFPGPIPNSLPQNIPPLTQTPVVVPPFLQPE & 3794.4 \\
\hline & & f57-93 & SLVYPFPGPIPNSLPQNIPPLTQTPVVVPPFLQPEVM & 4024.7 \\
\hline
\end{tabular}

Table 2 shows a selection of peptides identified in each fraction, focused on precursors of $\beta-\mathrm{CM}-7$ and neocasomorphin-6. In C5, no peptides of interest have been found.

antigen in crypt cells at the end of the oral treatment. No difference in the level of epithelial proliferation was detected between TP and CT rats (data not shown).

\subsubsection{Goblet cells and mucins}

The histological examination of intestinal slices revealed that $\beta$ $\mathrm{CN}(94-123)(0.1 \mu \mathrm{mol} / \mathrm{L})$ induced an increase in the number of duodenal goblet cells per crypt-villus axis as compared with controls (Table 3). This increase in the density of goblet cells was also observed in the jejunum and ileum but not in the colon (Table 3 and Supplemental Fig. 3). Quantitative RT-PCR analysis indicated that $\beta$ $\mathrm{CN}(94-123)$ modified the expression of Muc2 in the rat small intestine (Table 4). Peptide gavage also induced a significant increase in duodenal, jejunal and ileal Muc4 mRNA expression (Table 5). At the protein level, Western blot analysis confirmed the increased expression of Muc4 in intestinal epithelium of rat receiving $\beta$ $\mathrm{CN}(94-123)$ compared to controls $(P<.05)$ (Fig. 4).

\subsubsection{PCs and antimicrobial molecules}

A characteristic feature of small intestinal host defense is the presence of PCs at the bottom of the crypts of Lieberkühn. Oral administration of $\beta-\mathrm{CN}(94-123)(100 \mu \mathrm{mol} / \mathrm{L})$ increased the percentage of crypts showing PCs along the intestinal tract (Supplemental Fig. 3 and Fig. 5A), which would suggest an improved state of mucosal protection. The effect of $\beta-\mathrm{CN}(94-123)$ on the percentage of crypts exhibiting PCs was retained when the peptide was administered at the concentration of $0.1 \mu \mathrm{mol} / \mathrm{L}$ (duodenum) or $0.01 \mu \mathrm{mol} / \mathrm{L}$ (jejunum, ileum). As shown in Fig. 5B, a marked increase in expression of rat defensin 5 (rdefa5) mRNA transcripts was also observed in the duodenum, jejunum and ileum of TP rats. Likewise, lysozyme mRNA transcripts were significantly augmented in the small intestine of TP rats when compared with $\mathrm{CT}$ intestinal tissue (data not shown). Western blot analysis confirmed the increased expression of lysozyme in intestinal epithelium of rat receiving $\beta-\mathrm{CN}(94-123)$ compared to controls $(P<.05)$ (Fig. 5C).

\subsubsection{Enteroendocrine cells}

Because, in the small intestine, enteroendocrine cells, goblet cells and PCs arise from a common secretory progenitor [26], the distribution of enteroendocrine cells was examined with the panendocrine marker chromogranin A. $\beta-\mathrm{CN}(94-123)$ did not modify the number of enteroendocrine cells in the small intestine or in the colon (data not shown). These data indicate that $\beta-\mathrm{CN}(94-123)$ specifically changes the quantitative distribution of intestinal cells of secretory lineage that are directly involved in protection of the intestinal mucosa.

\section{Discussion}

The intestinal barrier, an ultimate interface maintaining the whole intestinal homeostasis, is a functional unit including the epithelial layer itself and factors such as peristalsis, gut microbiota, mucus and different secreted constituents such as defensins, lysozymes and immunoglobulins. Among these factors, intestinal mucus plays a critical role in the protection against acidic aggression, luminal proteases, mechanical insults, colonization by pathogenic bacteria and potential carcinogens $[8,27,28]$. The major component of the intestinal mucus is the gel-forming mucin MUC2, which is produced by goblet cells of the epithelium [29]. It should be noted that a second class of mucins, transmembrane-associated mucins, also plays a role in the protection of epithelia, in particular by providing a steric barrier that can limit direct access of pathogens [30]. They are anchored to the apical cell surface of epithelial cells and are a major component of the glycocalyx. In the intestine, MUC4 is one of such prominent transmembrane-associated mucins [31]. In the present study, we showed that proteolysis of caseins by lactic bacteria (L. delbrueckii ssp. bulgaricus and S. salivarius ssp. thermophilus) as fermented in yoghurt leads to the formation of many peptides including precursors of $\beta$ CMs or of neocasomorphin-6. We also established that the TPP obtained from a marketed yoghurt induces mucin secretion and the expression of MUC2 and MUC4. These effects were dose-dependent, the maximum response being observed when the peptide pool was administered at a concentration corresponding to that found in yoghurts. Our results thus revealed that peptides active on mucus cells are produced in sufficient quantity in this fermented dairy product to modulate in vitro the secretion and expression of gastrointestinal mucins. Surprisingly, we failed to detect mucin-like glycoprotein secretion in response to $\mathrm{C} 3, \mathrm{C} 4$ or $\mathrm{C} 5$ fractions (despite the fact that $\mathrm{C} 3$ and $\mathrm{C} 4$ fractions contained peptides with the sequence of $\beta-\mathrm{CM}-7$ inside). This implies that the components responsible for the biological effect are specific to the $\mathrm{C} 2$ fraction. We succeeded in identifying the sequence [94-123] of $\beta$-casein, present only in $\mathrm{C} 2$ fraction, as most likely the active molecule of this fraction and of the yoghurt. Indeed, $\beta-C N(94-123)$ increased production of the intestinal secreted mucin MUC2 and of the transmembrane-associated mucin MUC4 when tested in vitro (0.01$1 \mu \mathrm{mol} / \mathrm{L}$ ) on human intestinal HT29-MTX goblet-like cells. Interestingly, $\beta-C M-7$, which is the reference milk bioactive peptide, enhanced intestinal mucins production only when administered at $100 \mu \mathrm{mol} / \mathrm{L}$ [7]. Most importantly, we demonstrated that the effect of $\beta-C N(94-123)$ was also observed in vivo. Indeed, one daily oral administration of $\beta-\mathrm{CN}(94-123)(0.1-100 \mu \mathrm{mol} / \mathrm{L})$ in rats between postnatal days 10 and 18 significantly increased the number of goblet cells along the small intestine. These effects were associated with an enhanced expression of intestinal mucins (Muc2 and Muc4). This is of 
A

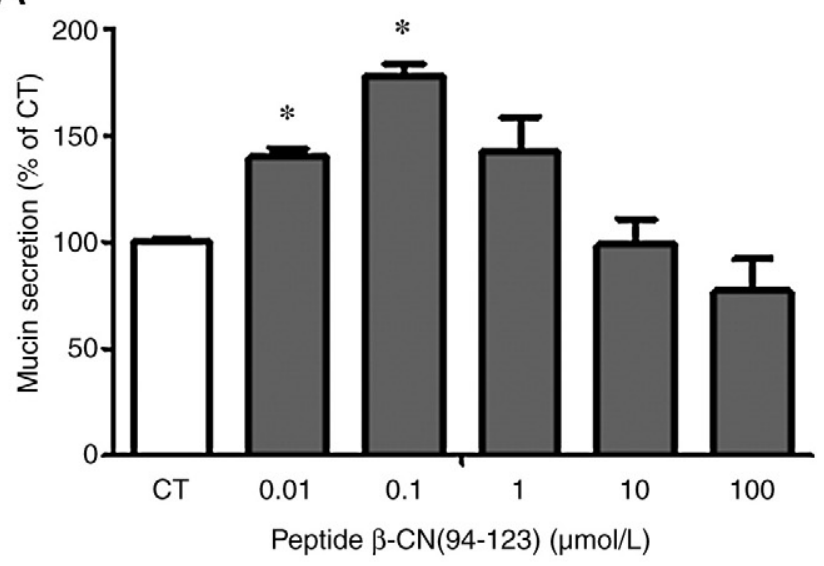

$\mathrm{B}$
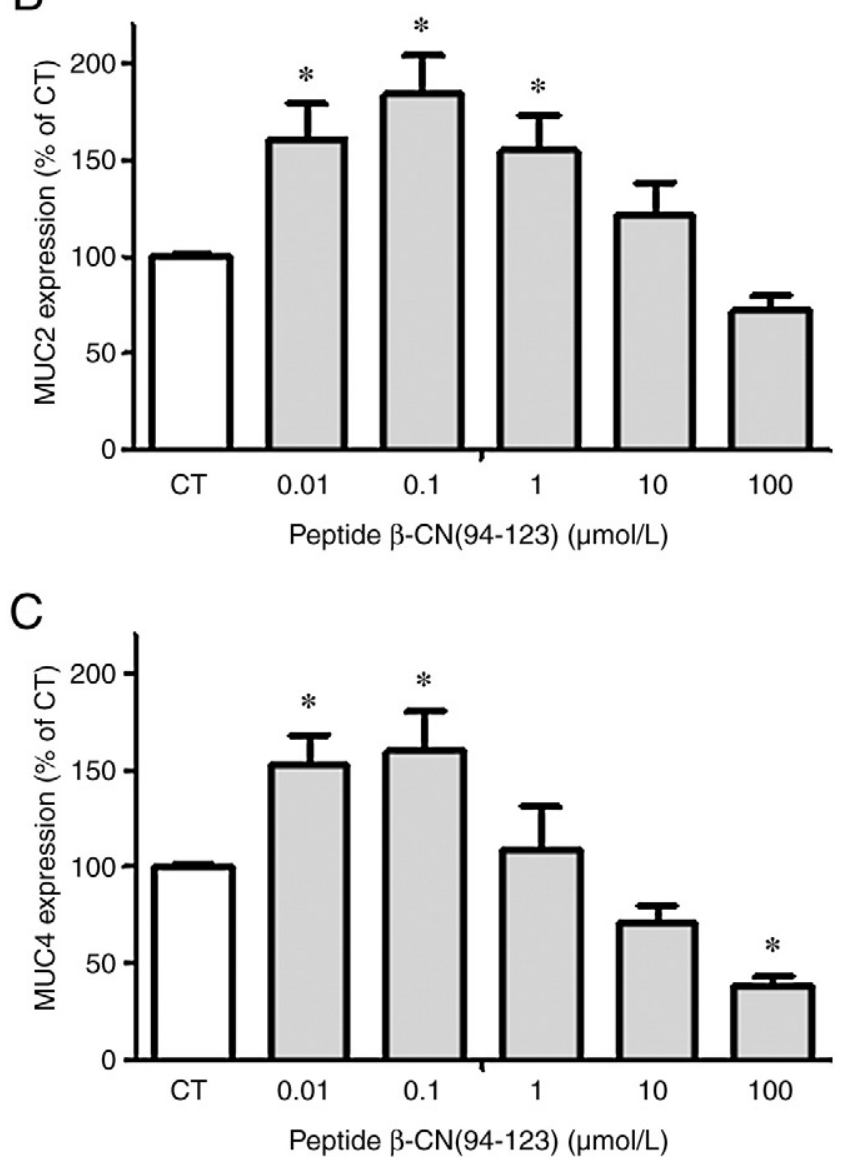

Fig. 3. Peptide $\beta-\mathrm{CN}(94-123)$ dose dependently increases mucin-like glycoprotein release as well as the level of MUC2 and MUC4 mRNA in HT29-MTX cells (4-h exposition). Each bar represents the mean percent increase vs. controls \pm S.E.M. of four experiments performed in triplicate. ${ }^{*} \mathrm{P}<.05$ vs. controls. (A) The amount of mucin glycoproteins in culture media was measured by ELLA. (B and C) Total RNA was isolated, and mucin mRNA levels (MUC2 and MUC4) were analyzed by quantitative RTPCR. Quantitative RT-PCR products of cyclophilin A mRNA, used as internal control, were unaffected by $\beta-\mathrm{CN}(94-123)$.

great consequence as, although biological activity of some food products may be demonstrated in vitro, activity may be lost in vivo after ingestion as the bioactive peptide may be degraded during digestion or may not attain active concentrations in target tissues. It should be noted however that $\beta-\mathrm{CN}(94-123)$ had no effect on colonic mucus cells. This could be due to the fact that dietary peptides that
Table 3

Quantitative immunohistochemistry (number of goblet cells) after oral administration of the peptide $\beta-\mathrm{CN}(94-123)$

\begin{tabular}{llllr}
\hline & $\begin{array}{l}\text { Duodenum } \\
\text { (number of } \\
\text { mucus cells/ } \\
\text { crypt-villus } \\
\text { axis) }\end{array}$ & $\begin{array}{l}\text { Jejunum } \\
\text { (number of } \\
\text { mucus cells/ } \\
\text { crypt-villus } \\
\text { axis) }\end{array}$ & $\begin{array}{l}\text { lleum } \\
\text { (number of } \\
\text { mucus cells/ } \\
\text { crypt-villus } \\
\text { axis) }\end{array}$ & $\begin{array}{l}\text { Colon } \\
\text { (number } \\
\text { of mucus } \\
\text { cells/crypt) }\end{array}$ \\
\hline Control group & $6.65 \pm 0.11$ & $7.75 \pm 0.14$ & $7.89 \pm 0.14$ & $9.90 \pm 0.31$ \\
Peptide $(0.01 \mu \mathrm{mol} / \mathrm{L}$ ) & $6.57 \pm 0.23$ & $8.01 \pm 0.18$ & $7.61 \pm 0.18$ & $9.22 \pm 0.13$ \\
Peptide $(0.1 \mu \mathrm{mol} / \mathrm{L})$ & $8.86 \pm 0.15^{*}$ & $9.30 \pm 0.25^{*}$ & $9.79 \pm 0.09^{*}$ & $10.04 \pm 0.02$ \\
Peptide $(100 \mu \mathrm{mol} / \mathrm{L})$ & $6.61 \pm 0.16$ & $11.12 \pm 0.17^{*}$ & $10.54 \pm 0.17^{*}$ & $9.61 \pm 0.05$
\end{tabular}

Counts were performed on tissue sections ( $\times 20$ magnification $)$ and were expressed as the mean number of goblet cells per intestinal crypt-villus axis (means \pm S.E.M., $n=8$ ) or per colonic crypt (S.E.M., $n=8$ ).

* $P<.05$ vs. controls.

escape digestion and enter the large intestine are rapidly broken down by colonic microbiota.

Remarkably enough, $\beta-\mathrm{CN}(94-123)(0.01-100 \mu \mathrm{mol} / \mathrm{L})$ also enhanced the number of PCs in the duodenum of rats. A significant effect on PCs was even observed in the jejunum and in the ileum as soon as the concentration of $0.01 \mu \mathrm{mol} / \mathrm{L}$. This increase in PCs was associated with a rise of lysozyme and rdefa5 expression. In agreement with our results, Thoreux et al. demonstrated that the number of PCs significantly rose in the three portions of the small intestine of mice receiving a diet supplemented with yoghurt [32]. The mechanism responsible for this effect was not further investigated however. Our study is thus the first to identify a bioactive molecule that regulates this epithelial cell population. PCs are key effectors of innate immunity. These epithelial cells are located at the base of the crypts of the small intestine and are characterized by the presence of apical secretory granules containing high levels of antimicrobial factors such as lysozyme, $\alpha$-defensins (cryptdins in mice), phospholipase A2 and the C-type lectins RegIII $\gamma[33,34]$. In humans, the $\alpha$-defensins found in PCs are $\alpha$-defensin-5 and -6 (HD-5 and HD-6) [35]. PCs play an essential role in controlling intestinal barrier penetration by pathogenic or commensal bacteria, in regulating the intestinal microbiota and in maintaining homeostasis of the small intestinal stem cell niche [36-39]. It should be noted that antibacterial factors secreted by PCs are retained by the mucus barrier, which allows it to regulate bacteria that are in close contact with the intestinal surface. The simultaneous stimulation of goblet cells and PCs induced by $\beta-C N(94-123)$ should thus synergistically decrease susceptibility to microbial invasion and enhance intestinal protection. Interestingly, several studies suggested that consumption of fermented milks may reinforce mucosal integrity of the intestine. For example, dietary supplementation with milk fermented by $L$. casei DN-114 001 strongly decreased the diarrhea symptoms, infection and injuries of the intestinal epithelial cells in a model of suckling rats infected with rotavirus [40]. Vinderola et al. also demonstrated the effectiveness of the nonbacterial fraction of fermented milk in prevention against Salmonella typhimurium infection [41]. The mechanisms proposed to explain the fermented milk properties included improvement of the lactose digestion and of

Table 4

RT-PCR analysis of Muc2 after oral administration of $\beta-\mathrm{CN}(94-123)$ from postnatal day 10 to 18

\begin{tabular}{lrlrl}
\hline & Duodenum & Jejunum & \multicolumn{1}{c}{ Ileum } & \multicolumn{1}{l}{ Colon } \\
\hline Control group & $100.0 \pm 1.3$ & $100.0 \pm 1.2$ & $100.0 \pm 1.7$ & $100.0 \pm 2.7$ \\
Peptide $(0.01 \mu \mathrm{mol} / \mathrm{L})$ & $83.2 \pm 0.8$ & $102.3 \pm 1.8$ & $98.0 \pm 1.4$ & $115.1 \pm 3.9$ \\
Peptide $(0.1 \mu \mathrm{mol} / \mathrm{L})$ & $84.0 \pm 1.3$ & $152.2 \pm 1.1^{*}$ & $104.3 \pm 1.1$ & $107.4 \pm 2.5$ \\
Peptide $(100 \mu \mathrm{mol} / \mathrm{L})$ & $90.1 \pm 1.0$ & $139.5 \pm 1.8^{*}$ & $84.8 \pm 1.0$ & $121.2 \pm 1.5$ \\
\hline
\end{tabular}

The expression of each gene was normalized to the reference gene level in each sample. The results are expressed as the percentage of $C T$ rats (means \pm S.E.M., $n=8$ per group). $* P<.05$ vs. controls. 
Table 5

RT-PCR analysis of Muc4 after oral administration of $\beta-\mathrm{CN}(94-123)$ from postnatal day 10 to 18

\begin{tabular}{lcccr}
\hline & Duodenum & Jejunum & \multicolumn{1}{l}{ Ileum } & \multicolumn{1}{l}{ Colon } \\
\hline Control group & $100.0 \pm 1.7$ & $100.0 \pm 2.8$ & $100.0 \pm 2.1$ & $100.0 \pm 1.2$ \\
Peptide $(0.01 \mu \mathrm{mol} / \mathrm{L})$ & $156.5 \pm 1.3^{*}$ & $160.3 \pm 1.4^{*}$ & $157.2 \pm 2.2^{*}$ & $102.8 \pm 3.4$ \\
Peptide $(0.1 \mu \mathrm{mol} / \mathrm{L})$ & $120.1 \pm 1.5$ & $94.7 \pm 1.2$ & $84.1 \pm 2.7$ & $92.6 \pm 5.6$ \\
Peptide $(100 \mu \mathrm{mol} / \mathrm{L})$ & $121.0 \pm 1.4$ & $161.4 \pm 2.1^{*}$ & $113.1 \pm 1.7$ & $103.0 \pm 4.7$ \\
\hline
\end{tabular}

The expression of each gene was normalized to the reference gene level in each sample. The results are expressed as the percentage of CT rats (means \pm S.E.M., $n=8$ per group). $* P<.05$ vs. controls.

the intestinal ecology by their antibacterial and immunostimulating effects. Our data provide an alternative explication, showing that bioactive peptides such as $\beta-\mathrm{CN}(94-123)$ may play a major role in this protective effect. Works are in progress in our laboratory to validate this hypothesis by analysis of the effects of $\beta-\mathrm{CN}(94-123)$ in several models of intestinal epithelial alterations.

How could we explain the effects of $\beta-\mathrm{CN}(94-123)$ on goblet cells and PCs? An exciting possibility will be that $\beta-\mathrm{CN}(94-123)$ could induce changes in epithelial differentiation since we found a significant rise in the density of goblet cells and PCs in the small intestine of treated rat. Furthermore, the lack of effect of $\beta-\mathrm{CN}(94-$ 123) on enteroendocrine cells as well as on proliferation of epithelial cells in the small intestinal mucosa could suggest a specific action on the two cell lineages directly involved in intestinal protection. To confirm this hypothesis, further studies will be conducted to determine the impact of the peptide on the expression of transcription factors (Hath1, Gfi1, Klf4,...) involved in the differentiation of goblet cell and PC lineages [26]. However, we cannot exclude that $\beta-\mathrm{CN}(94-123)$ could increase transcription of the gel-forming mucin MUC2 in already differentiated goblet cells of the intestine since, in vitro, it can enhance the expression of this mucin after direct application on differentiated intestinal goblet-like cells HT29-MTX.

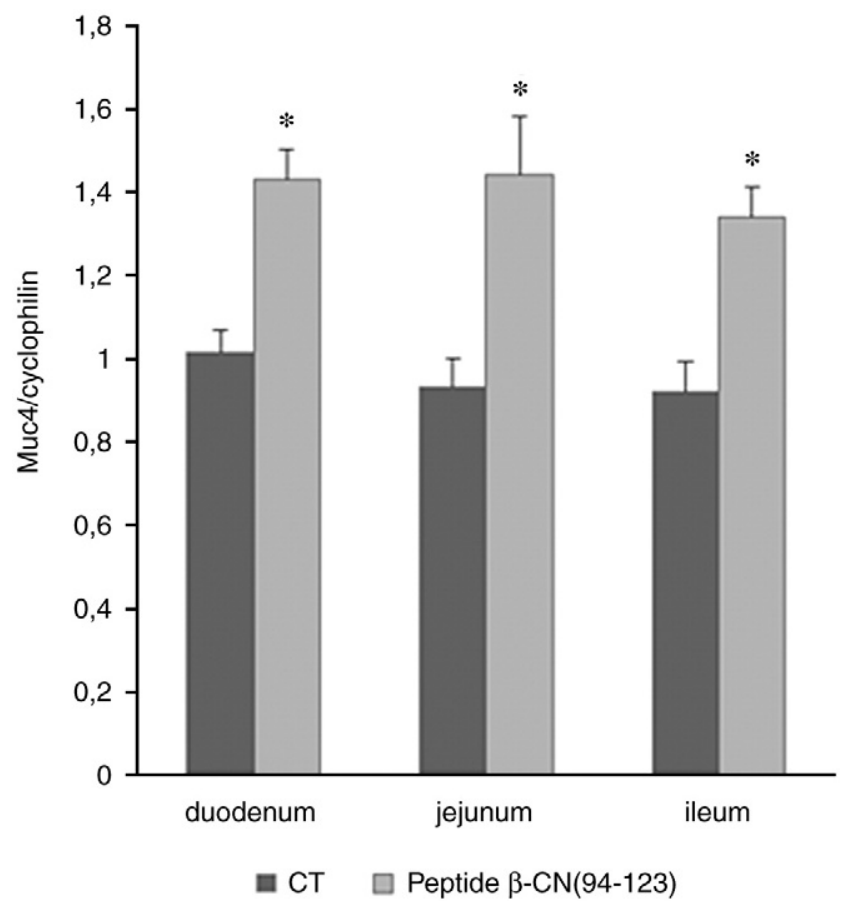

Fig. 4. Western blot analysis of Muc4 in the small intestine after administration of $\beta$ $\mathrm{CN}(94-123)(0.01 \mu \mathrm{mol} / \mathrm{L}, 9$ days). The expression of Muc4 was normalized to the reference gene level (cyclophilin $A$ ) in each sample. Data are mean \pm S.E.M. ${ }^{*} P<.05$ vs. controls ( $n=8$ per groups). CT: control rat; TP: rat treated with the peptide.
It is interesting to note that the effect of $\beta-\mathrm{CN}(94-123)$ observed in vivo on Muc2 and Muc4 expression was very similar to that obtained when tested in vitro on HT29-MTX cells, suggesting a direct action of $\beta-\mathrm{CN}(94-123)$ through receptors located on the intestinal goblet cells. Consequently, it is likely that $\beta-\mathrm{CN}(94-123)$ or a shorter active form resulting from its partial digestion resists the action of digestive enzymes and reaches the duodenum but also the distal part of the small intestine. The length of the peptide makes the identification of the active sequence difficult. One possible candidate for the activation of goblet cells could have been the sequence $\beta-\mathrm{CN}$ f114-119 (neocasomorphin-6), which was previously identified as an opioid receptor agonist [26]. However, we can exclude in our study the involvement of the mu-opioid pathway. Indeed, the effect of $\beta$ $\mathrm{CN}(94-123)$ on mucin production in vitro was not inhibited by cyprodime, an antagonist of the mu-opioid pathway. Furthermore, we previously showed that $\beta-\mathrm{CM}-7$, an opioid peptide, induces the expression of MUC5AC in HT29-MTX cells, while our peptide had no effect on this mucin [7]. At last, the effects of $\beta-\mathrm{CN}(94-123)$ on goblet cells and PCs could be explained by the amino acid composition of this peptide. Interestingly, $\beta-\mathrm{CN}(94-123)$ contains 30 amino acids including 5 proline residues, making it more resistant to degradation by digestive enzymes. This peptide that we identified in several marketed yoghurts at concentrations ranging between 0.3 and $1.7 \mu \mathrm{mol} / \mathrm{L}$ thus seems also to be resistant to degradation by enzymes of lactic acid bacteria. Now, if we consider the activity of other preponderant amino acids (E, K) of $\beta-C N(94-123)$ on intestinal functions, we can note that protective effects of glutamic acid have been characterized. Luminal L-glutamate ( 1 and $10 \mathrm{mmol} / \mathrm{L}$ ) was demonstrated to enhance mucus gel thickness via the activation of afferent nerves [42]. Therefore, one can hypothesize that the peptide could be hydrolyzed to amino acids and then L-glutamate triggers the activation of mucus cells. However, as the peptide is administered at very low doses, it is unlikely that L-glutamate could be present in the intestinal lumen in sufficient quantities. Moreover, this indirect effect described by Akiba et al. involved a nervous pathway and therefore cannot explain the action of the peptide on HT29-MTX cells. Other studies are needed to determine the mechanisms by which peptide $\beta$ $\mathrm{CN}(94-123)$ exerts its activity. It thus will be possible to optimize the nutritional and health effects of this molecule. Furthermore, having identified this bioactive peptide present in yoghurts is an exciting challenge for trying to boost its synthesis and hopefully the potential health effect of these fermented milks.

Surprisingly, the effect of $\beta-\mathrm{CN}(94-123)$ on HT29-MTX cells was the most prominent at a concentration of $0.01 \mu \mathrm{mol} / \mathrm{L}$, and it was reversed when tested at $100 \mu \mathrm{mol} / \mathrm{L}$. One possible explanation for these results is that the interaction of $\beta-\mathrm{CN}(94-123)$ with a putative receptor would reach saturation, thus leading to a paradoxical inhibitory effect. Another explanation may be that our peptide potentially contains several bioactive sequences showing antihypertensive (f108-113, f114-115), opioid (f114-119) and antioxidant (f 98-105) activities [43-45]. One of these potentially active sequences could be recognized as a signal when the peptide is tested at 100 $\mu \mathrm{mol} / \mathrm{L}$ in HT29-MTX cells and then reduce mucin production. The effect of each bioactive sequence on the secretion and expression of mucins is to be determined in vitro. Special attention should be paid to the opioid sequence f114-119. Data from the literature have indeed shown that opioid peptides including $\alpha$-casomorphins are able to interact with somatostatin receptors [46,47], which are also present on intestinal epithelial cells as well as on the parental HT29 cells. Somatostatin, synthesized and secreted by endocrine D cells of the stomach and intestine, is known to exert an inhibitory control in the gut. On the basis of these data, we can hypothesize that interaction with somatostatin receptors could explain the reversed effect of $\beta$ $\mathrm{CN}(94-123)$. Additional experiments are required to validate this hypothesis. Anyway, it is important to note that the reverse action of 

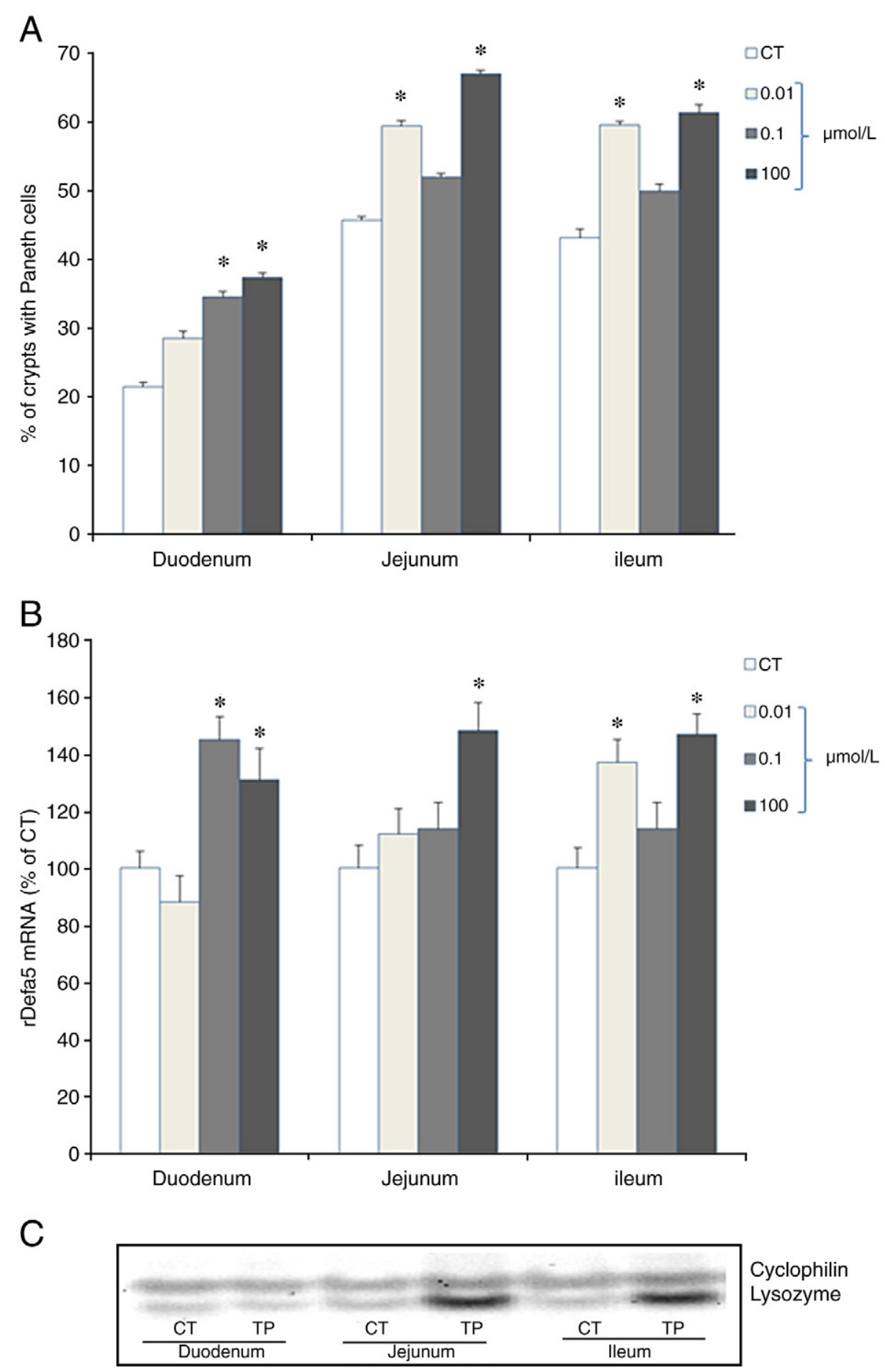

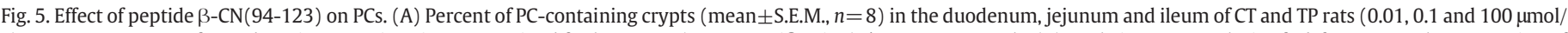

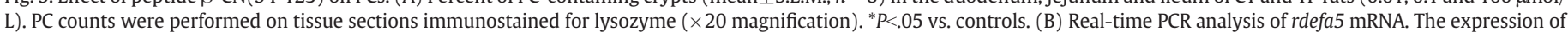

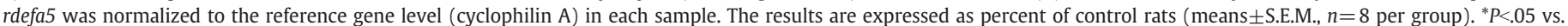

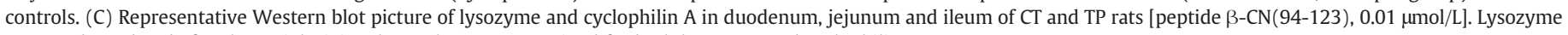
appeared as a band of $17 \mathrm{kDa}$. Eight jejunal samples were examined for both lysozyme and cyclophilin A.

$\beta-C N(94-123)$ on MUC2 and MUC4 expression was observed in vitro when the peptide was tested at a high concentration $(100 \mu \mathrm{mol} / \mathrm{L})$. We can speculate that such an inhibition could not take place after normal consumption of dairy products. Indeed, on the one hand, we have not detected such a concentration in fermented milks, and on the other hand, when the peptide was tested in vivo at the same high concentration, we observed no reversed effect as compared with rat receiving vehicle alone.
In conclusion, our study demonstrated that bioactive peptides that are formed in yoghurts during the hydrolysis of milk proteins by lactic acid bacteria are produced in sufficient quantities to achieve an effect on intestinal epithelial cells. Among these peptides, $\beta-\mathrm{CN}(94-123)$, which corresponds to the fragment (94-123) of bovine $\beta$-casein, modulates Paneth and mucus cells, the two intestinal epithelial cell populations that play a crucial role in intestinal protection. Because of its resistance to the digestive phase and its strong effects on two 
major actors of the intestinal barrier, $\beta-\mathrm{CN}(94-123)$ is particularly pertinent to restore normal intestinal homeostasis and could play an important role in protection against damaging agents of the intestinal lumen.

\section{Acknowledgments}

We thank D. Mollé for mass spectrometry assistance and B. Le Nevé and M. El Homsi for technical assistance.

\section{Appendix A. Supplementary data}

Supplementary data to this article can be found online at http:// dx.doi.org/10.1016/j.jnutbio.2012.05.004.

\section{References}

[1] Korhonen H, Pihlanto A. Food-derived bioactive peptides - opportunities for designing future foods. Curr Pharm Des 2003;9:1297-308.

[2] Hartmann R, Meisel H. Food-derived peptides with biological activity: from research to food applications. Curr Opin Biotechnol 2007;18:163-9.

[3] Teschemacher H, Koch G, Brantl V. Milk protein-derived opioid receptor ligands. Biopolymers 1997;43:99-117.

[4] Jinsmaa Y, Yoshikawa M. Enzymatic release of neocasomorphin and betacasomorphin from bovine beta-casein. Peptides 1999;20:957-62.

[5] Quito FL, Seybold VS, Brown DR. Opiate binding sites in mucosa of pig small intestine. Life Sci 1991;49:PL219-22.

[6] Nano JL, Fournel S, Rampal P. Characterization of delta-opioid receptors and effect of enkephalins on IRD 98 rat epithelial intestinal cell line. Pflugers Arch 2000;439: 547-54.

[7] Zoghbi S, Trompette A, Claustre J, El Homsi M, Garzon J, Jourdan G, et al. betaCasomorphin-7 regulates the secretion and expression of gastrointestinal mucins through a mu-opioid pathway. Am J Physiol Gastrointest Liver Physiol 2006;290: G1105-13.

[8] Deplancke B, Gaskins HR. Microbial modulation of innate defense: goblet cells and the intestinal mucus layer. Am J Clin Nutr 2001;73:1131S-41S.

[9] McGuckin MA, Linden SK, Sutton P, Florin TH. Mucin dynamics and enteric pathogens. Nat Rev Microbiol 2011;9:265-78

[10] Velcich A, Yang W, Heyer J, Fragale A, Nicholas C, Viani S, et al. Colorectal cancer in mice genetically deficient in the mucin Muc2. Science 2002;295:1726-9.

[11] Van der Sluis M, De Koning BA, De Bruijn AC, Velcich A, Meijerink JP, Van Goudoever JB, et al. Muc2-deficient mice spontaneously develop colitis, indicating that MUC2 is critical for colonic protection. Gastroenterology 2006;131:117-29.

[12] Pugh S, Jayaraj AP, Bardhan KD. Duodenal mucosal histology and histochemistry in active, treated and healed duodenal ulcer: correlation with duodenal prostaglandin E2 production. J Gastroenterol Hepatol 1996;11:120-4.

[13] Strugala V, Dettmar PW, Pearson JP. Thickness and continuity of the adherent colonic mucus barrier in active and quiescent ulcerative colitis and Crohn's disease. Int J Clin Pract 2008;62:762-9.

[14] Mudter J. From intestinal stem cells to inflammatory bowel diseases. World J Gastroenterol 2011;17:3198-203.

[15] Gibson PR, Muir JG. Reinforcing the mucus: a new therapeutic approach for ulcerative colitis? Gut 2005;54:900-3.

[16] Claustre J, Toumi F, Trompette A, Jourdan G, Guignard H, Chayvialle JA, et al. Effects of peptides derived from dietary proteins on mucus secretion in rat jejunum. Am J Physiol Gastrointest Liver Physiol 2002;283:G521-8.

[17] Trompette A, Claustre J, Caillon F, Jourdan G, Chayvialle JA, Plaisancie P. Milk bioactive peptides and beta-casomorphins induce mucus release in rat jejunum. J Nutr 2003;133:3499-503.

[18] Meisel H. Chemical characterization and opioid activity of an exorphin isolated from in vivo digests of casein. FEBS Lett 1986;196:223-7.

[19] Muehlenkamp MR, Warthesen JJ. Beta-casomorphins: analysis in cheese and susceptibility to proteolytic enzymes from Lactococcus lactis ssp. cremoris. J Dairy Sci 1996;79:20-6.

[20] De Noni I, Cattaneo S. Occurrence of $\beta$-casomorphins 5 and 7 in commercial dairy products and in their digests following in vitro simulated gastro-intestinal digestion. Food Chem 2010;119:560-6.
[21] Schieber AHB. Characterization of oligo- and polypeptides isolated from yoghurt. Eur Food Res Technol 2000;210:310-3.

[22] Boutrou R, Jardin J, Blais A, Tome D, Leonil J. Glycosylations of kappa-caseinderived caseinomacropeptide reduce its accessibility to endo- but not exointestinal brush border membrane peptidases. J Agric Food Chem 2008;56:8166-73.

[23] Livak KJ, Schmittgen TD. Analysis of relative gene expression data using realtime quantitative PCR and the $2(-$ Delta Delta $C(T)$ ) method. Methods 2001;25: 402-8.

[24] Pfaffl MW, Horgan GW, Dempfle L. Relative expression software tool (REST) for group-wise comparison and statistical analysis of relative expression results in real-time PCR. Nucleic Acids Res 2002;30:e36.

[25] Ogg CL. Determination of nitrogen by the micro-Kjeldahl method. J Assoc Off Anal Chem 1960:43:689-94.

[26] van der Flier LG, Clevers H. Stem cells, self-renewal, and differentiation in the intestinal epithelium. Annu Rev Physiol 2009;71:241-60.

[27] Corfield AP, Carroll D, Myerscough N, Probert CS. Mucins in the gastrointestinal tract in health and disease. Front Biosci 2001;6:D1321-57.

[28] Corazziari ES. Intestinal mucus barrier in normal and inflamed colon. J Pediatr Gastroenterol Nutr 2009;48(Suppl. 2):S54-5.

[29] Allen A, Hutton DA, Pearson JP. The MUC2 gene product: a human intestinal mucin. Int J Biochem Cell Biol 1998;30:797-801.

[30] Moniaux N, Escande F, Porchet N, Aubert JP, Batra SK. Structural organization and classification of the human mucin genes. Front Biosci 2001;6:D1192-206.

[31] Rong M, Rossi EA, Zhang J, McNeer RR, van den Brande JM, Yasin M, et al. Expression and localization of Muc4/sialomucin complex (SMC) in the adult and developing rat intestine: implications for Muc4/SMC function. J Cell Physiol 2005;202:275-84.

[32] Thoreux K, Balas D, Bouley C, Senegas-Balas F. Diet supplemented with yoghurt or milk fermented by Lactobacillus casei DN-114 001 stimulates growth and brushborder enzyme activities in mouse small intestine. Digestion 1998;59:349-59.

[33] Ouellette AJ. Paneth cell alpha-defensins in enteric innate immunity. Cell Mol Life Sci 2011;68:2215-29.

[34] Bevins CL, Salzman NH. Paneth cells, antimicrobial peptides and maintenance of intestinal homeostasis. Nat Rev Microbiol 2011;9:356-68.

[35] Wehkamp J, Chu H, Shen B, Feathers RW, Kays RJ, Lee SK, et al. Paneth cell antimicrobial peptides: topographical distribution and quantification in human gastrointestinal tissues. FEBS Lett 2006;580:5344-50.

[36] Sherman MP, Bennett SH, Hwang FF, Sherman J, Bevins CL. Paneth cells and antibacterial host defense in neonatal small intestine. Infect Immun 2005;73: 6143-6.

[37] Vaishnava S, Behrendt CL, Ismail AS, Eckmann L, Hooper LV. Paneth cells directly sense gut commensals and maintain homeostasis at the intestinal host-microbial interface. Proc Natl Acad Sci USA 2008;105:20858-63.

[38] Wehkamp J, Stange EF. Paneth's disease. J Crohns Colitis 2010;4:523-31.

[39] Zhang C, Sherman MP, Prince LS, Bader D, Weitkamp JH, Slaughter JC, et al. Paneth cell ablation in the presence of Klebsiella pneumoniae induces necrotizing enterocolitis (NEC)-like injury in the small intestine of immature mice. Dis Model Mech 2012;5:522-32.

[40] Guerin-Danan C, Meslin JC, Chambard A, Charpilienne A, Relano P, Bouley C, et al. Food supplementation with milk fermented by Lactobacillus casei DN-114 001 protects suckling rats from rotavirus-associated diarrhea. J Nutr 2001;131: 111-7.

[41] Vinderola G, Matar C, Perdigon G. Milk fermented by Lactobacillus helveticus R389 and its non-bacterial fraction confer enhanced protection against Salmonella enteritidis serovar typhimurium infection in mice. Immunobiology 2007;212: 107-18.

[42] Akiba Y, Watanabe C, Mizumori M, Kaunitz JD. Luminal L-glutamate enhances duodenal mucosal defense mechanisms via multiple glutamate receptors in rats. Am J Physiol Gastrointest Liver Physiol 2009;297:G781-91.

[43] Philanto-Leppälä A, Rokka T, Korhonen H. Angiotensin I converting enzyme inhibitory peptides derived from bovine milk proteins. Int Dairy Journal 1998;8: 325-31.

[44] Hernandez-Ledesma B, Amigo L, Ramos M, Recio I. Application of highperformance liquid chromatography-tandem mass spectrometry to the identification of biologically active peptides produced by milk fermentation and simulated gastrointestinal digestion. J Chromatogr A 2004;1049:107-14.

[45] Gobbetti M, Minervini F, Rizzello CG. Angiotensin I-converting-enzyme-inhibitory and antimicrobial bioactive peptides. Int J Dairy Technol 2004:57:173-88.

[46] Hatzoglou A, Kampa M, Castanas E. Opioid-somatostatin interactions in regulating cancer cell growth. Front Biosci 2005;10:244-56.

[47] Notas G, Kampa M, Nifli AP, Xidakis K, Papasava D, Thermos K, et al. The inhibitory effect of opioids on HepG2 cells is mediated via interaction with somatostatin receptors. Eur J Pharmacol 2007;555:1-7. 